\title{
On Statistical Overview of Disease Causing Child Mortality in Ondo State, Nigeria
}

\section{Kupolusi JA' ${ }^{1}$, Adebola FB ${ }^{1}$ and Adebayo $\mathrm{OT}^{2 *}$}

${ }^{1}$ Department of Statistics, Federal University of Technology, Akure, Nigeria

${ }^{2}$ Department of Computer Science, Federal university of Technology, Akure, Nigeria

\begin{abstract}
Infant mortality constitutes an important indicator of health and social environment of a society. Mortality is an important issue in public health, most especially for developing countries like Nigeria. This paper has been able to look critically into the health sector of Ondo State, Akure by looking into the aspect of Infant mortality, still birth and possible causes of infant mortality. The summary of the Chi-square results show that there is no significant difference between the type of disease causing infant mortality and gender while the regression analysis identifies the diseases contributing more to infant mortality such as severe anaemia, pneumonia and still birth asphyxia.
\end{abstract}

Keywords: Infant Mortality Rate (IMR); Still Birth Rate (SBR); Anova

\section{Introduction}

Infant mortality depends on different factor like socio economic condition, environment, and terrestrial location. Mortality is an important issue in public health, most especially for developing countries like Nigeria. This will later in future become a major concern to human society because of its serious effect on population.

After mid- $20^{\text {th }}$ century, studies and science advances have been made in controlling health related issues all round the world and increasing trend of life expectancy, average life span and reducing the mortality trend till today. Health is very important indicator which regulates the economic position of a state. A country's infant mortality rate is only a reflection of the quality of health delivery available to the citizens and to a large extent a reflection of the quality of life enjoyed by the citizens of a country.

\section{Background of study}

Several studies have been carried out on infant and child mortality using Census, Living Standards and Demographic Health Survey (DHS) data. Booth [1] used profit analysis to model child mortality in Pakistan and found that girls have a significant lower probability of dying in age group 0-1 but have a significant higher probability of dying in the age group 1-5. Thus the higher mortality of girls in the age group 1-5 reflects discrimination against girls in the form of lower health and other resource inputs.

The hazard rate framework is utilized by Van der and Wang [2], in which a flexible parametric framework for analysing infant and child mortality is developed. Their model predicts that a significant number of under-five child deaths can be averted by providing electricity, improving the education of women, providing sanitation facilities and reducing in-door air pollution. Wang investigated [3] the determinants of child mortality in LDCs using Demographic and Health Surveys data from over 60 low income countries. The results show that at the national level access to electricity, incomes, vaccination and public health expenditure significantly reduce child mortality. For the rural sample, vaccination is the only significant predictor for child mortality while access to electricity is the only significant mortality determinant in the urban sample. Although pooled cross-sectional data improves model performance because of the rich source of data, country specific effects are not captured. Field [4] examined the impact of maternal literacy and numeracy skills, formal education and adult literacy course participation on child health inputs (vaccinations and postnatal care) and child mortality in Ghana. He adopted an Instrumental Variable
(IV)-based two-Stage Least Squares (2SLS) estimation technique to account for the potential endogeneity of maternal skills, schooling and adult literacy course participation. His preliminary results revealed that formal schooling, adult literacy course participation and literacy and numeracy skills have a positive impact on child health input demand and hence reduce child mortality. The author recommended improvement in child health knowledge through the inclusion of health topics in the curricula of adult literacy programmes.

Thomas [5] employed logistic regression for analysing child mortality in a cross-section of countries. The study found mother's and father's education as significant determinants of child mortality in poor countries. Heisler [6] estimated the socioeconomic determinants of child mortality in Pakistan using sequential probit model. The study posits that breastfeeding protects children from early exposure to diseases and ill health and that mother's education is strongly related to neonatal mortality, infant mortality and child mortality through improved child caring practices. Proximate determinants such as prenatal care, income and environmental conditions were also found to be significantly related to child mortality.

In 2009, just few days on the assumption of office, Governor Olusegun Mimiko of Ondo State was welcomed with the shocking revelation from the World Bank through its operations officer; Anne Fisher said that Ondo State was carrying a huge burden of high rate of maternal and infant mortality in Nigeria. This news was a big challenge for a governor who has background as a medical doctor and commitment to transform the health sector especially in the rural areas. A home-gown strategy [7-9] to reverse the ugly indices of death, tagged the "ABIYE safe motherhood programme" become the answer to tackle the challenge. The aim of Abiye safe motherhood is to make sure that infant mortality is brought down drastically in Ondo State. Several factors cause infant mortality which include; Severe Anaemia Neonatal Sepsis, Neonatal Jaundice, Premature, Pneumonia and Still Birth Asphyxia.

*Corresponding author: Adebayo OT, Department of Computer Science Federal University of Technology, Akure, Nigeria, Tel: +234 806579 3988; E-mail: adebayoot@futa.edu.ng

Received May 23, 2017; Accepted June 16, 2017; Published June 20, 2017

Citation: Kupolusi JA, Adebola FB, Adebayo OT (2017) On Statistical Overview of Disease Causing Child Mortality in Ondo State, Nigeria. J Health Med Informat 8 : 264. doi: $10.4172 / 2157-7420.1000264$

Copyright: @ 2017 Kupolusi JA, et al. This is an open-access article distributed under the terms of the Creative Commons Attribution License, which permits unrestricted use, distribution, and reproduction in any medium, provided the original author and source are credited. 
Citation: Kupolusi JA, Adebola FB, Adebayo OT (2017) On Statistical Overview of Disease Causing Child Mortality in Ondo State, Nigeria. J Health Med Informat 8: 264. doi: 10.4172/2157-7420.1000264

Page 2 of 4

\section{Methods and Materials}

The Infant Mortality Rate (IMR) and Still Birth Rate (SBR) are calculated using the following formulas respectively:

$$
\begin{aligned}
& S B R_{\text {year }}=\sum_{i-\text { jan }}^{\text {dec }} \frac{\text { stillbirth }}{\text { livebirth }+ \text { stillbirth }} \times 1000 \\
& S B R_{\text {year }}=\sum_{i-\text { jan }}^{\text {dec }} \frac{\text { stillbirth }}{\text { livebirth }+ \text { stillbirth }} \times 1000
\end{aligned}
$$

\section{Definition of Terms}

Infant: It simply means a child less than one year.

Mortality: It simply means death.

Rate: Are conventional indices for measuring population experience with respect to fertility, mortality and morbidity. Rate is number of relevant event over population at risk multiply by $\mathrm{k}$, where $\mathrm{k}$ is usually 1000 .

Infant mortality: Is defined as death before baby's first birthday.

Infant mortality rate: Is the number of death aged less than one year divided by number of live birth per 1000

Still birth rate: Is the number of still birth to number of total birth per 1000 .

Still birth asphyxia: Perinatal Asphyxia, neonatal asphyxia, or birth asphyxia is the medical condition resulting from deprivation of oxygen to a new-born infant that lasts long enough during the birth process to cause physical harm, usually to the brain. Hypoxic damage can occur to most of the infant's organs (heart, lungs, liver, gut, kidneys), but brain damage is of most concern and perhaps the least likely to quickly or completely heal.

Pneumonia: Pneumonia is a bacterial or viral infection of the lung. The most commonly bacteria are called streptococcus pneumonia but viral pneumonia is more common in children. A baby born prematurely has greater risk of developing pneumonia.

Neonatal jaundice: New-born jaundice is when a baby has a high level of bilirubin in the blood. Bilirubin is a yellow substance that body creates when it replaces old red blood cells.

Neonatal sepsis: Neonatal sepsis is invasive infection, usually bacterial, occurring during the neonatal period. Sign are multiple and include diminished spontaneous activity, temperature and jaundice.

Severe anaemia: Anaemia is a disorder in which there are too few red blood cells in the blood. Anaemia can occur when red blood cells are broken down too rapidly, too much blood is lost, or the bone marrow does not produce enough red blood cells.

The Tables 1a-1f shows the summary of infant mortality rate and still birth rate for the period of 2005-2014. The Figure la shows the trend pattern of the infant mortality rate and still birth rate for the period of ten years (2005-2014). It shows that the rate of infant mortality for the year interval was increasing at an increasing rate while that of still birth was increasing at a decreasing rate.

From the Figure $1 \mathrm{~b}$ above the number of male live birth is of high increase than that of female live birth, which shows that the number of male birth is more Figure $1 \mathrm{c}$ than that of female birth. The male takes $51.1 \%$ of the total live birth while that of female live birth is $48.9 \%$ Figure $1 \mathrm{~d}$.

The Figure 1e above shows the six diseases consider in this research

\begin{tabular}{|c|c|c|c|c|c|c|c|c|c|c|}
\hline \multicolumn{10}{|c|}{ Year } \\
\hline Rate & $\mathbf{2 0 0 5}$ & $\mathbf{2 0 0 6}$ & $\mathbf{2 0 0 7}$ & $\mathbf{2 0 0 8}$ & $\mathbf{2 0 0 9}$ & $\mathbf{2 0 1 0}$ & $\mathbf{2 0 1 1}$ & $\mathbf{2 0 1 2}$ & $\mathbf{2 0 1 3}$ & $\mathbf{2 0 1 4}$ \\
\hline IMR & 19.4 & 25.7 & 47.2 & 42.3 & 43.1 & 35.3 & 41 & 28.2 & 27.1 & 43 \\
\hline SBR & 39 & 35.5 & 22.4 & 34.3 & 54.1 & 31 & 23.5 & 21.3 & 13 & 19.1 \\
\hline
\end{tabular}

Table 1a: Gender summation of live rate for the period of 2005-2014.

\begin{tabular}{|c|c|c|c|c|c|c|c|c|c|c|}
\hline \multicolumn{10}{|c|}{ Year } \\
\hline Rate & $\mathbf{2 0 0 5}$ & $\mathbf{2 0 0 6}$ & $\mathbf{2 0 0 7}$ & $\mathbf{2 0 0 8}$ & $\mathbf{2 0 0 9}$ & $\mathbf{2 0 1 0}$ & $\mathbf{2 0 1 1}$ & $\mathbf{2 0 1 2}$ & $\mathbf{2 0 1 3}$ & $\mathbf{2 0 1 4}$ \\
\hline Male & 1089 & 865 & 1177 & 1877 & 1718 & 1686 & 1110 & 1279 & 1484 & 995 \\
\hline Female & 1079 & 847 & 1047 & 1835 & 1689 & 1570 & 1070 & 1343 & 1247 & 960 \\
\hline
\end{tabular}

Table 1b: Gender summation of live birth for the period of 2005-2014.

\begin{tabular}{|c|c|c|c|c|c|c|c|c|c|c|}
\hline \multicolumn{10}{|c|}{ Year } \\
\hline $\begin{array}{c}\text { Still } \\
\text { Birth }\end{array}$ & $\mathbf{2 0 0 5}$ & $\mathbf{2 0 0 6}$ & $\mathbf{2 0 0 7}$ & $\mathbf{2 0 0 8}$ & $\mathbf{2 0 0 9}$ & $\mathbf{2 0 1 0}$ & $\mathbf{2 0 1 1}$ & $\mathbf{2 0 1 2}$ & $\mathbf{2 0 1 3}$ & $\mathbf{2 0 1 4}$ \\
\hline Male & 44 & 35 & 28 & 75 & 95 & 63 & 30 & 28 & 20 & 19 \\
\hline Female & 44 & 28 & 23 & 57 & 100 & 41 & 21 & 29 & 16 & 19 \\
\hline
\end{tabular}

Table 1c: Gender summation of still birth for the period of 2005-2014

\begin{tabular}{|c|c|c|c|c|c|c|c|c|c|c|}
\hline \multicolumn{10}{|c|}{ Year } \\
\hline $\begin{array}{c}\text { Infant } \\
\text { Death }\end{array}$ & $\mathbf{2 0 0 5}$ & $\mathbf{2 0 0 6}$ & $\mathbf{2 0 0 7}$ & $\mathbf{2 0 0 8}$ & $\mathbf{2 0 0 9}$ & $\mathbf{2 0 1 0}$ & $\mathbf{2 0 1 1}$ & $\mathbf{2 0 1 2}$ & $\mathbf{2 0 1 3}$ & $\mathbf{2 0 1 4}$ \\
\hline Male & 23 & 23 & 62 & 88 & 75 & 60 & 41 & 38 & 34 & 49 \\
\hline Female & 19 & 21 & 43 & 69 & 72 & 55 & 46 & 36 & 40 & 35 \\
\hline
\end{tabular}

Table 1d: Gender summation of infant death for the period of 2005-2014.

\begin{tabular}{|c|c|c|c|c|c|c|c|c|c|c|}
\hline \multicolumn{10}{|c|}{ Year } \\
\hline Diseases & $\mathbf{2 0 0 5}$ & $\mathbf{2 0 0 6}$ & $\mathbf{2 0 0 7}$ & $\mathbf{2 0 0 8}$ & $\mathbf{2 0 0 9}$ & $\mathbf{2 0 1 0}$ & $\mathbf{2 0 1 1}$ & $\mathbf{2 0 1 2}$ & $\mathbf{2 0 1 3}$ & $\mathbf{2 0 1 4}$ \\
\hline $\begin{array}{c}\text { Severe } \\
\text { Anaemia }\end{array}$ & 2 & 4 & 6 & 15 & 12 & 9 & 7 & 3 & 8 & 7 \\
\hline
\end{tabular}

Table 1e: Diseases summary for the period of 2005-2014.

\begin{tabular}{|c|c|c|c|c|c|c|c|c|c|c|}
\hline \multicolumn{10}{|c|}{ Year } \\
\hline Diseases & $\mathbf{2 0 0 5}$ & $\mathbf{2 0 0 6}$ & $\mathbf{2 0 0 7}$ & $\mathbf{2 0 0 8}$ & $\mathbf{2 0 0 9}$ & $\mathbf{2 0 1 0}$ & $\mathbf{2 0 1 1}$ & $\mathbf{2 0 1 2}$ & $\mathbf{2 0 1 3}$ & $\mathbf{2 0 1 4}$ \\
\hline $\begin{array}{c}\text { Severe } \\
\text { Anemia }\end{array}$ & 2 & 4 & 6 & 15 & 12 & 9 & 7 & 3 & 8 & 7 \\
\hline $\begin{array}{c}\text { Neonatal } \\
\text { Jaundice }\end{array}$ & 1 & 5 & 2 & 17 & 19 & 15 & 3 & 17 & 12 & 7 \\
\hline $\begin{array}{c}\text { Neonatal } \\
\text { Sepsis }\end{array}$ & 3 & 1 & 4 & 21 & 21 & 16 & 11 & 9 & 7 & 8 \\
\hline $\begin{array}{c}\text { Premature } \\
\text { Pneumania }\end{array}$ & 7 & 4 & 9 & 20 & 23 & 13 & 12 & 10 & 9 & 8 \\
\hline $\begin{array}{c}\text { Birth } \\
\text { Asphyxia }\end{array}$ & 11 & 9 & 12 & 15 & 27 & 17 & 20 & 21 & 16 & 18 \\
\hline
\end{tabular}

Table 1f: Diseases summary for the period of 2005-2014.

TREND PATTERN OF INFANT MORTALITY RATE AND STILL BIRTH RATE

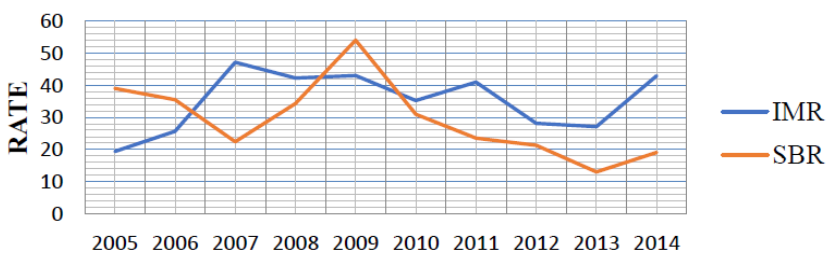

Figure 1a: Trend pattern of infant mortality rate and still birth rate from 2005-2014.

work that cause infant mortality on yearly bases. It was reveals that birth Asphyxia $[10,11]$ has the highest death of $166(24.7 \%)$, pneumonia follow with $118(17.6 \%)$, premature 115 (17.1\%), neonatal sepsis 101 
Citation: Kupolusi JA, Adebola FB, Adebayo OT (2017) On Statistical Overview of Disease Causing Child Mortality in Ondo State, Nigeria. J Health Med Informat 8: 264. doi: 10.4172/2157-7420.1000264

Page 3 of 4

(14.6\%), neonatal jaundice has $98(14.6 \% 0$, and severe anaemia with the least has 73 death (10.9\%).

In order to ascertain the most prevalence disease that causes child mortality can be better explained by regression analysis. Regression analysis measures the relationship between two or more variables.

\section{Coefficient of determination}

From the Tables $2 a-2 c, R 2=0.699$. This implies [12] that $69.9 \%$ of the variation in $\mathrm{Y}$ is explained by the explanatory variables of the model.

Decision rule: Reject $\mathrm{H}^{\circ}$ if prob. of significance is less than $\alpha$, else do not reject.

Conclusion: Since sig $>a(0.489>0.05)$, we have the statistical reason not to reject $\mathrm{H}^{\circ}$ and conclude that There is no significant difference between the type of disease causing infant mortality and gender [13].

\section{TREND PATTERN OF LIVE BIRTH}

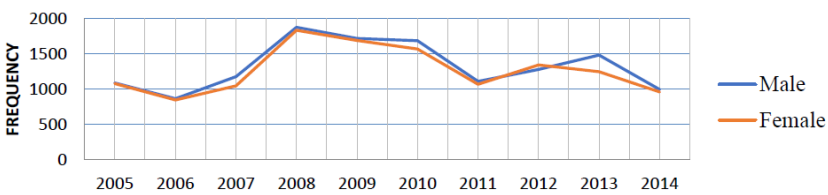

Figure 1b: Trend pattern of live birth.

Multiple bar chart on still birth

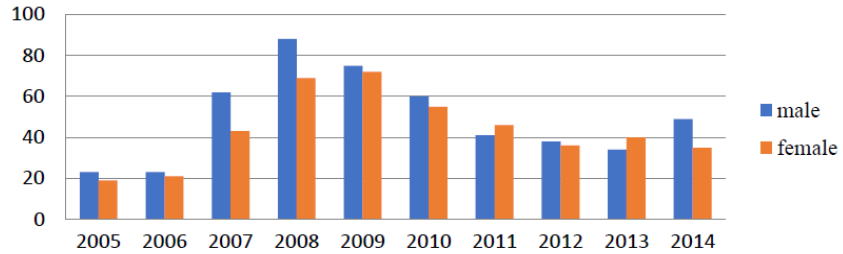

Figure 1c: Multiple bar charts on still birth.

\section{Multiple bar chart on infant death}

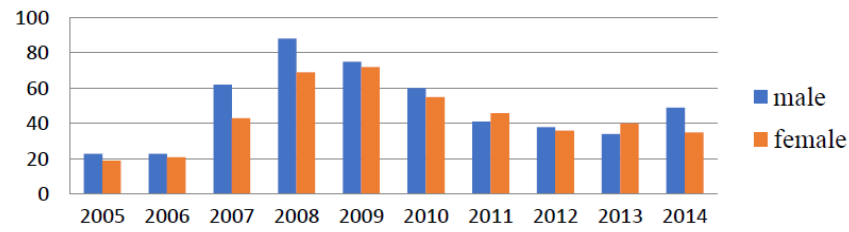

Figure 1d: Multiple bar chart on infant death

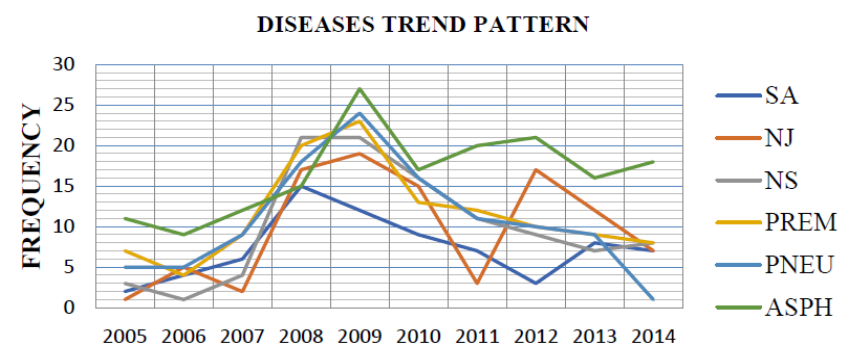

Figure 1e: Showing diseases trend pattern for the period of 2005-2014.

\begin{tabular}{|c|c|c|c|c|}
\hline \multicolumn{5}{|c|}{ Model Summary } \\
\hline Model & $\mathbf{R}$ & R Square & Adjusted R Square & $\begin{array}{c}\text { Std. Error of the } \\
\text { Estimate }\end{array}$ \\
\hline 1 & $0.836 a$ & 0.699 & 0.098 & 8.98846 \\
\hline
\end{tabular}

Table 2a: Regression analysis.

\begin{tabular}{|c|c|c|c|c|c|}
\hline Model & Sum of Squares & Df & Mean Square & F & Sig. \\
\hline Regression & 563.424 & 6 & 93.904 & 1.162 & $0.489 a$ \\
\hline Residual & 242.377 & 3 & 80.792 & & \\
\hline Total & 805.801 & 9 & - & - & - \\
\hline
\end{tabular}

Table 2b: ANOVA summary.

\begin{tabular}{|c|c|c|c|c|c|}
\hline & \multicolumn{2}{|c|}{$\begin{array}{c}\text { Unstandardized } \\
\text { Coefficients }\end{array}$} & $\begin{array}{c}\text { Standardized } \\
\text { Coefficients }\end{array}$ & \\
\hline Model & B & Std. Error & Beta & T & Sig. \\
\hline 1 (Constant) & 16.033 & 13.493 & - & 1.188 & 0.32 \\
\hline X1 & 1.885 & 2.04 & 0.797 & 0.924 & 0.42 \\
\hline X2 & -1.038 & 0.732 & -0.763 & -1.42 & 0.25 \\
\hline X3 & -0.231 & 1.557 & -0.167 & -0.15 & 0.89 \\
\hline X4 & -1.157 & 1.938 & -0.718 & -0.6 & 0.59 \\
\hline X5 & 1.71 & 2.219 & 1.073 & 0.77 & 0.5 \\
\hline X6 & 0.661 & 1.074 & 0.378 & 0.615 & 0.58 \\
\hline \multicolumn{7}{|c|}{ Table 2c: Coefficient. A) Dependent variable: IMR. } \\
\hline
\end{tabular}

\section{Results and Discussion for Regression}

Regressing the infant mortality rate $(\mathrm{Y})$ on the independent variables Severe Anaemia (X1), Neonatal Jaundice (X2), Neonatal Sepsis (X3), Premature(X4), Pneumonia (X5) and Still Birth Asphyxia (X6).

$$
\hat{Y}=16.033+1.885 \hat{X}_{1}-1.038 \hat{X}_{2}-0.231 \hat{X}_{3}-1.157 \hat{X}_{4}+1.710 \hat{X}_{5}+0.660 \hat{X}_{6}
$$

From the fitted regression equation it was shown that a unit increase in infant mortality rate will cause 1.885 increase in Severe Anaemia, 1.038 decrease in neonatal jaundice, 0.231 decrease in neonatal sepsis, 1.157 decrease in premature, 1.710 increase in pneumonia and 0.661 increase in Still Birth Asphyxia. Basically, decreasing rate in any of the disease causing infant mortality here is as a result of establishment of 'Abiye' clinics initiated by the State government.

\section{Conclusion}

This paper has investigated infant mortality in Ondo State using the data on infant mortality based on six different type of disease causes collected from State Specialist Hospital, Akure between years 2005-2014. The chart was used to illustrate the infant mortality rate and still birth rate. The gender trend pattern of the live birth, gender chart on still birth and infant death also the diseases trend pattern for the given period of ten year (2005-2014) were critically examined. The figure helps to indicate that the trend of male is above that of the female which shows that male have contributed more to infant mortality in Ondo State. The figure shows that the number of infant mortality is of increase and decrease for the period of year while still birth decrease as we move from one year to another which can be refer to improvement in medical standard in Ondo State. 
Chi-Square Test was also used to check if there is any association between the type of cause of disease and gender. The result indicates that there is no association. Regression equation was introduced into the research work to check for the form of relationship that exists between the variables. Using the standardized coefficient of beta, the variables that impact the number of infant mortality mostly are:

- X1 (Severe Anaemia), this is a disorder in which there are too few red blood cells in the blood. Infant who lack a specific red blood cell enzyme [Glucose-6-Phosphate Dehydrogenase (G6PD)] are as a result of exposure of the mother and foetus to certain drugs used during pregnancy and may result in rapid breakdown of red blood cell. In order to avoid this, such infant should be treated with intravenous fluid followed by an exchange blood transfusion.

- X5 (Pneumonia) a bacterial or viral infection of the lung. It is an infection of the air sac in the lungs. A baby born prematurely has greater risk of developing pneumonia. This can be controlled the baby is treated with oxygen therapy to help clear the sputum from the lung and also intravenous fluid to correct dehydration. This particular disease causing infant mortality is commonly found in Africa where people hardly find necessary needs required to combat the problem.

- X6 (Still Birth Asphyxia) is a medical condition resulting from deprivation of oxygen to a new-born infant that lasts long enough during the birth process to cause physical harm usually to the brain. This can occur to most of the infant's organs (heart, gut, lungs, liver, kidneys), but brain damage is of most concern and perhaps the least likely to quickly or completely heal. In more pronounced cases, an infant will survive but with damage to the brain manifested as either mental such as developmental delay or intellectual disability or physical such as spasticity. This also results most commonly from a drop in maternal blood pressure or some other substantial interference with the blood flow to the infant's brain during delivery. This is caused by inadequate circulation or perfusion, impaired respiratory effort or inadequate ventilation. This particular disease called for the Ondo State government intervention to establish 'Abiye' hospital across the state for proper and adequate health delivery services and reduction in child mortality rate in the state. It is recommended that such clinic should be established in a situation of high rate of infant mortality to reduce the trend and health services closer to people.

It was revealed from the Figure 1e that still birth asphyxia contributed mostly to the problem.

\section{References}

1. Booth $H$ (2002) Decline mortality variation. Popul Stud 56: 1-10.

2. Van der KB, Wang $L$ (2003) Child mortality in rural India. World Bank Working Paper, World Bank, Washington, DC, USA.

3. Wang L (2003) Environmental determinants of child mortality: empirical results from the 2000 Ethiopia DHS. World Bank, Washington, DC, USA.

4. Field C (1997) The analysis of time-series: an introduction ( $5^{\text {th }}$ edn.). Chapman and Hall, Chris, NY, USA 39: 508.

5. Thomas D (1995) Human resources: development of economics. Volume 3 Publisher B.V. printed at RAND working paper.

6. Heisler EJ (2008) An analyst in health services, the infant mortality rate: comparisons and underlying factors.

7. Espo M (2002) Infant mortality and its underlying determinants in rural malawi, dissertation, University of Tampere Medical School, Finland.

8. Ayenigbara GO, Olorunmaye VB (2012) Investigating the causes of infant mortality in Akoko South West Local Government Area of Ondo State Nigeria Public Health Research.

9. Hartmann M (2009) Demographic methods for the statistical office. Pres Resea Dev Stat Swed 1: 1-154.

10. Ali M (2011) Principle of population and demography. WHO 1: 1-64.

11. Murray R, Stephens SLJ (2007) Schaum's outlines statistics. Statistics 4: 1-601.

12. National Centre for Health Statistics (2003) US standard certificate of live birth Rev 1: 1-3.

13. Fajimbola T (2009) Abiye safe motherhood: a case of leadership in turning the tide of infant mortality in Nigeria. Nig Healt $\mathrm{J}$ 1: 1-4. 